\title{
Ethnophilosophy and Public Morality in an African Tribe
}

\author{
Uche A. Dike \\ Department of Philosophy and Religious Studies, Faculty of Arts, Niger Delta University, Wilberforce Island, \\ Nigeria \\ Email: ucheuad@yahoo.com
}

Received 5 August 2014; accepted 23 March 2015; published 26 March 2015

Copyright (C) 2015 by author and Scientific Research Publishing Inc.

This work is licensed under the Creative Commons Attribution International License (CC BY). http://creativecommons.org/licenses/by/4.0/

(c) (i) Open Access

\section{Abstract}

The paper is a field research work delving into the ethnophilosophy of Ogba religion. Its focal point is on the people' worldview, as it pertains to life, public morality, value and Adamic sins in Ogba Land Rivers State, Nigeria. It posits that the natural or physical world is an extension of the supernatural or the spiritual and must be understood in that sense if a valid explanation about Ogba people' vision of life must be sufficiently compatible with their cosmology. In the area of public morality, the ethnophilosophy of Ogba people is holistic and integrated. Thus, anti social behaviours or abominations known as Adamic sins in this paper are viewed as disruptive of public order and morality. In this wise the people's weltanschauung provided value essence as a foundation for existence. Hence, inviolable sanctity of human life and good moral character ranked to be the highest value in Ogba Land.

\section{Keywords}

Ogba Land, Religion, Public, Moral, Value, Adamic Sins

\section{Introduction}

Ogba religion is a traditional system of belief in the Supreme Being, the ancestors and the deities. Ethno-philosophy has been on the vanguard of bringing the traditional concepts to limelight (Peters, 2013: p. 60). In this paper we cultivated it to answer some salient questions. Do the people of Ogba Land cherish public order? Do they have morals and values, notwithstanding, evils or Adamic sins in the world? What is their worldview about life on earth? Answers to these questions were proffered in this research using oral and literature approach.

Some scholars like Egerson (2013: p. 15) in their works have shown that if an analysis is carried out in a traditional institution answers will emerge. These answers are synonymous with the people's traditional philosophy 
or ethnophilosophy behind their cosmology or worldview. Therefore, a survey on Ogba traditional religion is a good attestation of her ethnophilosophy or traditional weltanschauung. It has evidenced that lofty ideals such as public morality etc. are desirable in a traditional community like Ogba Land. Therefore, this study will be of immense importance to those who want to understand the need for good principles of life, ethicality, morals and public order, despite the perennial problems created by Adamic sins. It will further show the role ethno-philosophy has played in understanding these concepts which are enshrined or are the basis of some concepts in Ogba traditional religion.

\section{The Ethnophilosophy of Life}

The ethnophilosophy of Ogba Traditional Religion in its basic religious tenets and theology postulates a theocentric society and culture. The traditional Ogba in his significant interactions in the universe of creatures is in intimate communion with the departed and venerable ancestors, the minor divinities (of good or evil spirits) and ultimately with the Supreme Deity-from whom all proceed and to whom all are eventually and ultimately accountable. Hence, the theological basis of, and justification for the assertion that the traditional African is incurably religious. For Iwe (1979: p. 135), the natural and supernatural, though logically distinguishable, are inseparable dynamically and in reality. And the divine, though transcendental essentially, is ever immanent operationally in human affairs.

Thus in the Ogba Ethnophilosophy and vision of life, a purely and exclusively naturalistic explanation or understanding of human life, its experiences is alien, insufficient, and therefore deficient, without the spiritual and supernatural dimension (Kalu, 1978: pp. 37-44). Traditional Ogba sees this universe as a plane of existence and operation involving man, the ancestors, divinities and the Supreme Being in a state of mutual, cyclic and reciprocal action, reaction and communion. Here is the theological or spiritual vision with which the Traditional or Ethnophilosophy has imbued the institutions and norms of the traditional cultures. From this also a traditional social weltanschauung had arisen enabling the Ogba to have an integral and holistic perception and interpretation of human experiences.

However, it must be remarked in the course of human history and experience, that this spiritual attitude, though basically positive and commendable, had led to excesses, through irrational and unwarranted appeals to the supernatural elements and forces and fanatical and vindictive pursuit of social justice especially in criminal cases where the offended may seek redress from the deities. Thus it can be said that Ethnophilosophy provided the traditional society with a theo-centric vision of life essentially holistic, spiritual and deeply religious (Edmund, 2010: p. 62).

\section{Public Morality in Ogba Peoples' Ethnophilosophy}

Every human society must have its basic and recognized norms of public order, for the collective pursuit and realization of the common good and welfare of its members. This social atmosphere of public order would necessarily embrace norms for the maintenance of public health, public security (of life and property), public peace (or freedom from violence and commotion), public morality (or the minimum standard of morality compatible with social and communal life), social justice (freedom from deprivation, oppression and exploitation) and the common good (the order of rights and responsibilities for meaningful personal and social fulfillment towards development and progress (Eke, 2014: Interview).

Ogba traditional society had its system of public order. Very prominent in this system are its norms of public morality. The measures for the maintenance of public morality were articulated in the spirit of the Ogba Traditional Religion which not only prescribed the sanctions against public immorality but also stood as an indispensable agent of social control in all areas of public morality and probity. Hence a scholar remarked:

The strong belief in spiritual immortality and reincarnation provided the necessary personal and social motivation and encouragement to subordinate one's moral life to the requirements of ethical discipline and public morality, which often came under divine sanctions. Man in danger of moral prevarication or embarking on a wrong course of action are advised to remember life-after-death and the laws of reincarnation under which the wicked are severely deprived and punished (John, 2000: p. 23).

A few examples here may serve to illustrate how the traditional public moral order is sustained by the spirit, sanctions and rituals of the Ogba Traditional Religion. 
As indicated earlier, the Ogba traditional philosophy of life or worldview is essentially spiritual and holistic, with the natural, spiritual and supernatural as one integrated reality. In the area of ethics, especially public morality, the traditional Ogba vision and attitude are holistic and integrated. Thus any event or human behaviour in disharmony with the normal order of nature is grossly anti-social and considered as an abomination and therefore disruptive of public order and public morality (Ejor, 2009: p. 17). Such abnormal events or anti-social human behaviour and actions considered as an abomination are also regarded as bad omen and offence against the deities whose impending vengeance is bound to be not only personal but also social and catastrophic in its consequences (Ifeanyi, 2014: Interview). To avert the disastrous consequences of abomination, the traditional Ogba society would exact not only material reparation by the offender but also the performance of prescribed religious ritual for the purification of the offender and the polluted society (land) and for the appeasement of the offended deities. Thus the traditional Ogba concept of immorality and sin is not only personal and theological but also eminently social and religious (Okwu, 2014: Interview).

The list of what the Ogba traditional morality considers as an abominations or Adamic sins is quite long and open-ended, especially with regard to natural aberrations or erratic manifestations of nature.

\section{Types of Adamic Sins or Abominations in Ogba Ethnophilosophy}

1) Murder;

2) Suicide by hanging;

3) Incest and other prohibited sexual relationships;

4) Various forms of stealing, especially of objects regarded as sacred such as yam;

5) Adultery by the wife or sexual relationship during a prohibited early period of widowhood;

6) Dying what was considered a "bad death" resulting from unusual causes or diseases, such as enlargement of the stomach or the scrotum, leprosy, small pox etc.;

7) A cock crowing at odd times in the night;

8) A coconut with two tendrils ("two heads");

9) All forms of unusual or abnormal developments at child-birth or child development, such as multiple births, cutting the upper teeth first, etc. (Chukwudi, 2014: Interview);

10) Kidnapping, dishonest life, cheating, unjust means of acquiring wealthy by misappropriation of other peoples wealth and money, indifferent attitude to fellow mankind, lack of respect for elders, over indulgence in worldly pleasures, adultery, not being committed to the worship of Chukwu Abiama God, lack of veneration of ancestors and breaking of taboos (Nso) laid down by Erisi deities and Ndokie ancestors etc. Ogba traditional or ethnophilosophy warned that the above Adamic traits which occupies the mind of the unpolished or unholy man leads to death as it manifested in the garden of Eden leading to the spiritual death of Adam. When a man is dead spiritually the above evils manifest more in his life. It goes further by this analysis that a society with much men who have enthrone Adamic knowledge in their mind will experience indiscriminate use of ware weapons-missiles, atomic bombs leading to lack of peace and global crises. hence for a nation to experience peace and tranquility, individuals must first annihilate these Adamic traits in their mind which abound in the society today.

In the occurrence of any abomination so defined in the Ogba traditional moral code, the society would believe that natural or social moral order has been disrupted or violated and that its restoration was imperative. Social sanctions must be invoked and inflicted and appropriate religious rituals performed if the culprit is to be absolved and freed, the polluted land purified, the offended deities appeased, and the disrupted natural and sociomoral order restored.

These dimensions are conspicuously in evidence in the event of the breach of public moral order. However, it must be remarked here that though the contribution of the ethnophilosophy of Ogba traditional religion to the maintenance of public order and morality was very significant, it was unable to temper and control the fanaticism and violent excesses with which the traditional society punished offenders and culprits. There is evidence to show that the spirit of the traditional moral code was one of hatred for both the offence and the offender, as the principle that the sinner should, where possible, perish with his/her sin, seemed to have been upheld. Thus until the advent of Christianity, the spirit of the Ogba religion was impotent in the face of dehumanizing traditional sanctions and public exposure of offenders to penal measures, destructive of human personality and dignity. While it is undebatable that the Ethnophilosophy of Ogba Religion contributed immensely to the traditional public order and security, it is convincingly arguable that its lapses and deficiencies in the area of human dignity and 
humanity clamoured for the historical advent of a religion of the vision, depth and spirit of Christianity. Going further on this line of thought would be going beyond the pale of our study to trespass into the zone of Comparative Religion.

\section{The Impact of Ethnophilosophy on Moral Value}

Value is a term which fields of learning operate. It is a relevant and important term in moral and political philosophy, Aesthetics, Psychology, Anthropology and Sociology, Economics and Fine Arts. It could be defined as follows:

Put very simply, value is the worth which we ascribe to a choice-choice of an object, an opinion, a course of action, a relationship, a role, an experience. In a choice one alternative is preferred... What this alternative is worth to us is its "value", and it takes its place in a hierarchy of values, relating to the various alternative and the various levels of choice (Masi, 2011: p. 102).

With this ethico-psychological engineering on the word, value, one may here briefly and practically state that the term value, may be defined as, and connotes, the worthiness, preciousness, importance, relevance and desirability of anything for any person or society. When values become so important, relevant and desirable in a given society, they take institutional forms with fixed patterns, structures and agencies. But it is with moral values that we are dealing here, in the context of the ethnophilosophy of Ogba people.

The traditional value system was strongly and deeply permeated by the traditional religion, that in spite of the overwhelming historical impact of Christianity or Islam and of religious conversions, its resistant nature and persistence are still in evidence in both its positive and negative aspects. The sociologist, Peil has identified the veneration of ancestors and polygyny as some of these persistent traditional practices that have resisted changes (Peil, 1977: pp. 22-23).

However, focusing more and directly on the traditional moral and social values, one perceives that the traditional religion and value had provided the foundation, leitmotiv and nourishment for these values, and guaranteed their existence.

In the hierarchy of Ogba traditional moral and social values, the inviolable sanctity of human life and good moral character rank highest. Life is perceived as the highest value. Proverbs, personal names, pithy sayings and aphorisms are copious and easily available to assert this priority of human life as value (Ogidi, 2014: Interview). On account of this paramount importance of human life as a value, the prescriptions of religious rituals, the provisions of the moral code, the institutions and structures of the kinship system are all upheld and channeled towards the preservation of human life.

A good character would among other things mean: chastity before marriage, hospitality, unselfishness, kindness, truthfulness, protection of women as the responsibility of men; keeping covenant, observing taboos, respect and honour for the aged; condemning stealing; falsehood and hypocrisy; avoidance of incest and other forms of sexual immorality (Ikechukwu, 2014: Interview). Other socio-moral values would include-social justice, solidarity and unity.

This Ethno-philosophical highlighting life and moral character as the highest moral values in Ogba Land must be seen as two aspects of one reality-namely human life and its moral quality. Traditional wisdom rooted the priority it accorded life and moral character in a definite theological logic and soteriology. Human life, on the natural plane, is the highest gift of the Creator to man the violation of it is the violation of the ordinance of God for man and society. Ogba traditional soteriology upheld good moral life as the basis for a blissful life after death and prerequisite for reincarnation. As Idowu rightly remarked:

As character makes for good social relations, it is laid upon every member of the community to act in such a way as to promote always the good of the whole body (Idowu, 1962: p. 157).

From the above submissions, it is easy to see what positive contribution the Ogba ethnophilosophy enshrined in her Religion has made to traditional public morality and the culture of moral and social values.

Thus, the ethno-philosophy of Ogba people is a harbinger and fertile ground for fostering the positive aspect of her belief systems which inculcates awareness of public order, moral values, life after death etc which are the embodiments of her traditional religion which in practice tends to annihilate Adamic sins among the Ogbas. 


\section{Conclusion}

Ogba ethnophilosophy of life upholds that the creatures in the physical world are in intimate contact with the departed and venerable ancestors. In other words, there is no compartmentalization between the mundane and the macrocosmic world. The Ogba worldview of the universe is therefore a global existence involving the ancestors, divinities and the Supreme Being in a mutual, cyclic and reciprocal action, reaction and communion.

Ogba traditional society has its systems of public order which are embodiments of ethicality or morality enshrined in her traditional religion which not only prescribes sanctions against Adamic sins but acts as an arbiter or agent of social control in all areas of public morality. What a traditional Ogba man may consider as an Adamic $\sin$ is inexhaustible, but we have given some examples in the preceding pages.

Value is therefore of utmost importance in Ogba Land and consists of the essential ethicalities that can promote peace, harmony, stability and public order in the land. Thus, dignity and good moral character rank the highest value in Ogba Land. The ethnophilosophy of Ogba people brings the aforementioned issues to limelight, thereby eliminating and discouraging Adamic sins which are still operational in the mind of many people in the society. Putting clearly Adamic Sins in our time is the perpetuation of evils in the world. They are known as (Nso) abomination or taboo in Ogba people's ethnophilosophy or weltanschauung. Such knowledge is devoid of positive civilization in our contemporary world.

\section{References}

Chukwudi, F. T. (2014). Oral Interview Granted 29th February at Obigwe-Ogba Land. Occupation: Hunter, Age: 71 Years.

Edmund, U. T. (2010). Theocentric Vision of African Traditional Religion. Lagos: Orange Books.

Egerson, J. T. (2013). Religion and Traditional Institutions in Africa. London: Green-Wood Publishers.

Ejor, V. I. (2009). The African Traditional Religion of the Yorubas. Ibadan: Fyne Publishers.

Eke, W. S. (2014). Oral Interview Granted 15th January 2014 at Omoku-Ogba Land. Occupation: Priest of Earth Deity, Age: 82 Years.

Idowu, E. B. (1962). Olodamare God in Yoruba Belief. London: Longman.

Ifeanyi, G. R. (2014). Oral Interview Granted 13th December 2013 at Okposi-Ogba Land. Occupation: Hunter, Age: 74 Years.

Ikechukwu, C. E. (2014). Oral Interview Granted 27th March 2014 at Obagi-Ogba Land. Occupation: Trader, Age: 69 Years.

Iwe, N. S. S. (1979). Christianity, Culture and Colonialism in Africa. Port Harcourt: College of Education.

Kalu, O. U. (1978). Precarious Visions: The African Perceptions of His World. In O. U. Kalu (Ed.), Readings in African Humanities. Enugu: Fourth Dimension Publishers.

Masi, I. W. (2011). Themes in the Socio-Ethical Values of African Religion. Port Harcourt: View Publishing Company.

Ogidi, R. B. (2014). Oral Interview Granted 5th March 2014 at Omoku-Ogba Land. Occupation: Farmer, Age: 72 Years.

Okwu, V. N. (2014). Oral Interview Granted 21st January 2014 at Obosi-Ogba Land. Occupation: Wood Caver, Age: 70 Years.

Peil, M. (1977). Consensus and Conflict in African Societies. London: Longman.

Peters, F. U. (2013). Religion and Ethno-Philosophy of Change. Oxford: Clarendon Press. 